\title{
Model of Implementing Bus Rapid Transit (BRT) Mass Public Transport Policy in DKI Jakarta Province, Indonesia
}

\author{
Sunardi Manampiar Sinaga ${ }^{1}$, Muchlis $\mathrm{Hamdi}^{2}$, Sadu Wasistiono ${ }^{3}$, Sampara Lukman $^{4}$ \\ 1,2,3,4 Institut Pemerintahan Dalam Negeri (IPDN), Indonesia \\ Email: sunardi.ms@gmail.com
}

\begin{abstract}
The purpose of this study is to find a model for implementing policies on the development of Bus Rapid Transit (BRT) based on mass public transportation in DKI Jakarta Province, Indonesia. This research uses qualitative methods with data collection techniques such as observation, in-depth interviews and literature study. Policy choices for developing mass public transportation based on BRT seem to remain a rational choice for overcoming traffic congestion in Jakarta. The ideal model of policy implementation to be developed in the future is an integrated BRT-based mass transit public transport policy model, not only paying attention to its sustainability but also being just.
\end{abstract}

Keywords: policy implementation model, mass public transportation, public transportation.

\section{A. INTRODUCTION}

One public problem that has emerged along with the development of urban society is the management of public transportation. Almost all major cities in Indonesia experience complex transportation problems including Jakarta. Even the city of Jakarta, the capital of the Republic of Indonesia, is predicted to experience a very acute stagnation due to protracted traffic jams. Jakarta as the center of national economic growth has an impact on the increasing need of people for fast transportation, and at the same time raises transportation problems.

Transportation is a very important means in supporting the success of a country's development, especially in supporting the economic activities of the society. The high diversity and characteristics of the community make transportation problems a crucial problem for stakeholders in government. Proper and careful planning in making policy is the first step needed in addressing transportation problems (Pambagio, 2013). The strategic role of transportation is because transportation has two important functions namely, as a driver of development and serving real activities (Sani, 2010).

Transportation problems, especially land transportation in Jakarta, still cause problems. Urban transportation problems generally include traffic congestion, parking, public transportation, pollution, and traffic order issues (Munawar, 2007). According to Parekesit (2014), the portrait of traffic congestion in Jakarta is basically caused by uncontrolled vehicle growth, inadequate availability and use of public transportation, and low traffic discipline. This congestion ultimately has a negative impact in the form of; 
loss of time and economic value due to low travel speeds and longer travel times, waste of energy, vehicle wear which results in high vehicle maintenance costs, causes air pollution and increases stress among road users.

Yafiz's research (2002), revealed that the causes of transportation problems in the city of Jakarta were route arrangements that were not yet based on market needs and that traffic awareness among drivers, officers, passengers, and road users was relatively low. While at the same time regular public transportation still discusses problems in the form of many vehicles that are not roadworthy, rampant pickpocketing and buskers, disorderly drivers waiting for passengers outside the terminal and at the crossroads. Likewise, the presence of street vendors who sell by the side of the road and the low discipline of road user traffic has contributed to the occurrence of congestion.

The high mobility of people and goods in Jakarta has not yet been matched by the availability of adequate, safe and comfortable public transportation. As a result, private motor vehicles, both four-wheeled vehicles, and motorcycles grew rapidly from year to year, not proportional to the growth in road length. DKI Jakarta Transportation Statistics Data shows that in 2013 the number of motor vehicles has reached 16,072,689 units, if all of these vehicles are arranged it will not suffice the length of roads in Jakarta which is only 6,936,843.26 meters, meaning that each one unit of motorized vehicles 7 only reaches 0,43 meters or when compared to the total road area in Jakarta $48,402,763.16 \mathrm{~m} 2$, then one unit of motorized vehicles only reaches $3.02 \mathrm{~m} 2$. While efforts to build roads are constrained by the limited land available, so the growth of the length of the road is very small compared to what is needed. In terms of travel needs, the number of daily trips to and from the city of Jakarta according to data reported by the Jakarta Transportation Department in 2015 was 25.7 million trips/day, consisting of 18.8 million trips/day in DKI Jakarta and 6.9 million trips/day Bodetabek to Jakarta. Of the 25.7 million trips/day, it is estimated that 25.2 million or the equivalent of $98 \%$ use private vehicles, while the proportion of public transport uses is only $2 \%$.

Referring to the various facts, an integrated urban public transportation system management policy is needed and is able to realize the availability of transportation services that are compatible with the level of traffic needs and orderly, safe, comfortable, and affordable costs with public purchasing power. Within this framework, the DKI Jakarta Government has established a policy to implement Macro Transportation Pattern (PTM) as stipulated in DKI Jakarta Regional Regulation Number 5 of 2014 concerning Transportation and DKI Jakarta Governor Regulation Number 103 of 2007 concerning Macro Transportation Patterns. PTM policy within the framework of the Macro Transportation Pattern is intended as an effort in order to realize a transportation system that is not only reliable but fair and sustainable in accordance with the position and authority of the DKI Jakarta Province as the capital of the Unitary State of the Republic of Indonesia. PTM's policy is aimed at structuring an effective, efficient, smooth and integrated transportation system. PTM's policies include the following policies: Develop- 
ment of Mass Public Transportation, Traffic Restrictions, and Network Capacity Building.

Regarding the Mass Public Transport Development Policy (AUM Development Policy), this policy was motivated by the fact that the high mobility of people and goods in Jakarta has not been matched by the availability of safe and comfortable public transportation. Therefore, the policy option for developing 10 public transportation is a rational choice in the efforts to arrange the urban public transportation system. For Wright \& Fjellstrom (2002), the choice of public transport options that are formulated into policy is a choice about the future of a city. In such a position, public transportation is supposed to play a role in improving the quality of life of city residents, such as making the community orderly and orderly, having a clear estimation of time, facilitating mobilization and being a benchmark for the progress of a city.

Until now, the Mass Public Transportation Development Policy in Jakarta that has been implemented is the Jabodetabek KRL, airport railways and BRT (Bus Rapid Transit), known as "Trans Jakarta", while others are in the process of development. Of the three types of public transportation, the development of BRT (Bus Rapid Transit) or known as "Trans Jakarta" has received special attention from the DKI Jakarta Government. In fact, it is often used as a political commodity towards the succession of leadership in DKI Jakarta. Trans Jakarta development is believed to be one of the urban public transportation management strategies that are able to overcome the problem of congestion in the capital and the availability of public transportation that is safe, comfortable, fast and cheap, which until now is a problem that has not been fully resolved. Building a fast bus-based mass transit system (BRT) is arguably the fastest and cheapest solution. Although it is recognized that the purpose of creating a public transportation network is not to eradicate congestion but to provide alternatives to the community, not to eradicate congestion.

Various studies related to transportation system policies in major cities around the world have been widely carried out (Wish, 1982; Wildon, 1939; Hafis, et al., 2013; Arista, 2018; Priyanto, 2018; Guntur, 2019; Suseno, 2019) However, there are still gaps that distinguish existing studies, especially in the model of implementing transportation development policies by the uniqueness of each region, which in this dissertation is the Special Capital Region of Jakarta. Therefore, the purpose of this study is to find a model for implementing policies on the development of Bus Rapid Transit (BRT) based on mass public transportation in DKI Jakarta Province, Indonesia.

\section{B. LITERATURE REVIEW}

According to Van Meter and van Horn (1975), there are six factors that determine the success of policy implementation, namely: basic measures and policy objectives, sources of policy, characteristics of implementing agencies, economic, social and politics, attitudes of implementers; and communication between organizations related to 
implementation activities.

Referring to this theory, things that need to be explored further, first, the size and objectives of the policy are needed to lead in implementing the policy, this is done in accordance with the planned program. Second, policy resources are the success of the policy implementation process that is influenced by the utilization of human resources, costs, and time (van Meter \& van Horn, 1975). The sources of these policies are indispensable for the success of a policy made by the government. Human resources are very important because as a source of policy mobilizers and implementers, capital is needed for smooth policy financing so as not to impede the policy process. Time is an important part of implementing policy because time is a supporter of policy success. Time resources are determinants of the government in planning and implementing policies.

Third, the success of the policy can be seen from the nature or characteristics of the agency/agency implementing the policy. This is very important because the performance of public policy implementation will be very much influenced by the right characteristics and is suitable for implementing agencies or agencies. Subarsono (2006), revealed the quality of policy is influenced by the quality or characteristics of the actors, the quality is the level of education, competence in the field, work experience, and moral integrity. The component of this model consists of formal structures of organizations and informal attributes of their personnel, besides that attention also needs to be paid to the ties of the implementing body with exhibitions and in the delivery of policies.

Fourth, the impact of economic, social and political conditions on public policy has been a major focus of attention over the past decade. van Meter and van Horn revealed that: the extent to which the external environment supports the success of established public policies, the external environment is economic, social and political. Supporting economic resources can support the successful implementation of policies and in the political environment, the support of political elites is needed in supporting the successful implementation of policies (van Meter \& van Horn, 1975).

Changes in economic, social and political conditions can affect the interpretation of the problem and thus will affect the way the program is implemented, variations in the political situation affect work performance. A change of government can result in changes in the way policies are implemented without changing the policy itself. $\backslash$ Fifth, the characteristics of the implementing agency include the bureaucratic structure, norms, and patterns of relationships that occur in the bureaucracy. The attitude of the implementers in carrying out their duties and responsibilities as policy implementers must be based on a disciplined attitude. This is done because it can affect the success of policy implementation, each agency implementing the policy must feel ownership of their respective duties based on a predetermined plan.

Changes in economic, social and political conditions can affect the interpretation of the problem and thus will affect the way the program is implemented, variations in the political situation affect work performance. A change of government can result in 
changes in the way policies are implemented without changing the policy itself.

Fifth, the characteristics of the implementing agency include the bureaucratic structure, norms, and patterns of relationships that occur in the bureaucracy. The attitude of the implementers in carrying out their duties and responsibilities as policy implementers must be based on a disciplined attitude. This is done because it can affect the success of policy implementation, each agency implementing the policy must feel ownership of their respective duties based on a predetermined plan.

Sixth, communication plays an important role for the ongoing coordination of policy implementation. Policy standards and objectives have an indirect effect on performance, what effect does this have on the dependent variable mediated by other independent variables. It is clear that providing public services will be affected by the manner in which standards and objectives of communication are for the implementer and the extent to which the standards and objectives facilitate supervision and law enforcement (van Meter \& van Horn, 1975). Standards and objectives indirectly impact the disposition of implementers by entering organized communication activities.

The relationship between resources and the economic, social, and political environment of implementing jurisdictions (or organizations) shows that the availability of fiscal and other resources can create demand by private citizens and organized interest groups - for participation in and successful implementation of the program ( van Meter \& van Horn, 1975). The prospect of benefit from this program can cause the group to be declared silent to suppress maximum participation. Based on the limited resources available, private and organized citizens' interests can choose to oppose policy on the basis that the benefits of participation are small compared to the potential costs.

Implementation of the policy itself is very strategic in the process of achieving a goal of government organizations because the implementation is an embodiment of government actions in achieving a particular goal. Implementation of the policy is intended to provide services or change the behavior of the community or target group. The focus of the analysis of the implementation of the policy will include efforts made by officials or institutions at the central level to obtain compliance from lower-level institutions or officials in their efforts to provide services or change behavior to the community or target group of the program concerned (Wahab, 2004). More than that Islamy (1984), through analysis of policy implementation, policymakers not only want to see the policy has been implemented by the community but also want to find out how far the policy has had positive and negative consequences for the community.

\section{METHOD}

This study is a qualitative study with a post-positivism paradigm, which seeks to reveal social reality or facts that are ontologically incomprehensible to human limitations (Chadwick et al., 1991; Moleong, 2002). Data collection techniques used in this study were observation, interview, and documentation study techniques. The data ob- 
tained were then analyzed through three stages namely data reduction, data presentation, and verification (Miles \& Huberman, 1984).

Determination of informants in this study using a purposive sampling technique. The informants in this study came from elements of the DKI Jakarta Provincial Government such as Deputy Governor for Transportation and Transportation Services, TransJakarta management elements, DKI Jakarta Provincial Organda, and Metro Jaya Regional Police Dirlantas. In addition to informants from some of the elements above, also selected informants from the elements of the Public Transportation Cooperative in DKI Jakarta, Public Transportation Entrepreneurs in DKI Jakarta, the Public Observer Public Transportation, and Observers of Public Transportation Policy.

\section{RESULTS AND DISCUSSION}

Transjakarta is the first and only international Bus Rapid Transit (BRT) system in Indonesia. For 15 years, Transjakarta has become a symbol of the renewal of road-based public transportation in Jakarta and even Indonesia, by implementing more humane systems and services for Jakarta residents. For policymakers, Transjakarta becomes learning material in building an affordable public transportation system but with standardized professional services. For citizens, having reliable public transportation is certainly a tremendous advantage, especially in terms of efficiency in transportation costs and time. Not only that, but residents are also used to queuing, giving priority seats to vulnerable groups (the elderly, pregnant women, mothers with children and disabilities) and more aware of gender issues in the modern public transportation system.

As the first public transportation system subsidized by the city government, Transjakarta is proof that other cities in Indonesia can also have a public transportation system managed by the city government. Even in the past few years, Transjakarta has become a benchmark for the BRT system for cities in Indonesia such as Semarang and Medan, even in Southeast Asia, where Transjakarta is the first BRT system to be built in Asia. Transjakarta is also a symbol of the evolution of road-based public transportation service management. The term "chasing deposit" is no longer heard, scheduling fleet operations that make bus arrivals more reliable to the regularity of the system where the Transjakarta fleet only stops at designated stops and bus stops.

Although there are many significant achievements achieved by Transjakarta, of course, it cannot be avoided that there are still many improvements that still need to be done by Transjakarta. At the same time, there is a lot of potentials that can be developed by Transjakarta for the next 15 years. As the backbone of urban transportation in Jakarta, with route achievements covering up to $60 \%$ of Jakarta and its surrounding areas, Transjakarta should not be complacent. Although it has been recognized as a reference and learning center for cities in Indonesia and Southeast Asia, the standardization of services and infrastructure of Transjakarta has not yet reached the global BRT Gold 
Standard. It is time for the TransJakarta management paradigm to be oriented towards a policy approach that is sustainable and equitable.

The policy choices for developing mass public transportation based on BRT seem to remain a rational choice for overcoming traffic congestion in Jakarta. The ideal model of policy implementation to be developed in the future is an integrated BRT-based mass transit public transport policy model, not only paying attention to its sustainability but also being just.

First, the DKI Jakarta Provincial Government should implement the management of mass public transportation into one operational management (single bus operator). The bus companies that exist with TransJakarta form a consortium to manage urban transportation services in an integrated operations management. The application of this single bus operator is done in addition to avoiding competition among bus operators in providing services, it is also intended to embrace all operators in order to survive in developing business. The management of BRT-based mass public transportation into a single bus operator at the same time guarantees investment certainty for consortium member bus operators. In addition, through a single bus operator, the community as users will get better service quality because it is based on the same Minimum Service Standards (SPM).

Second, the next need is to restructure routes based on community needs. This route restructuring is important given that at the operational level many public transport routes overlap and coincide with other modes of transportation. Even the existing routes in its development are not in accordance with the needs of the community for public transportation. These overlapping routes that are not based on community need not only have an impact on users but also on entrepreneurs and drivers. Unfair competition occurs because there is no access and no integration of existing routes. This condition results in public transport users having to make a lot of other modes of transportation such as taxis or motorcycle taxis and ultimately results in high costs for public transport users.

Third, the policy of developing mass public transportation based on BRT will only be effective when followed by a traffic restriction strategy. Such a strategy was carried out to control the operation of private vehicles and to encourage the conversion of private vehicle users to BRT-based public transportation. For this purpose, (1) the acceleration of the application of the electronic road payment system or Electronic Road Pricing (ERP). ERP implementation policy is considered the most effective way to overcome the traffic congestion that is still a daily problem in the Capital City of Jakarta; (2) increase raising parking fees and vehicle tax rates, especially private vehicles. Increasing the rates of the two types of tax is intended to encourage private motorists to switch to mass public transportation, one of which is BRT based; (3) an increase in parking taxes must also be followed by management strategies and the imposition of parking fees on onstreet spaces. Road congestion in Jakarta is also caused by the number of vehicle users 
who park their vehicles in the space owned by the road; and (4) implementing a strategy of providing special incentives for public transportation costs in the form of noncash to government employees and private employees. This special incentive strategy is a strategy that is able to encourage changes in habits for government employees and private employees who use private vehicles to switch to public transport vehicles. These four traffic restriction strategies are only believed to be able to overcome the problem of congestion, but more than that will support the policy of developing BRT-based public transportation on an ongoing basis.

Fourth, the effectiveness of policy implementation is also very much determined by the consistency and continuity of the enforcement of the rules on which policy operates. Crucial and requiring extra attention in implementing the policy of developing BRT-based mass transit is a matter of sterilizing BRT routes. The problem is that since BRT-based public transportation is operated, this transportation lane is not completely sterile from other road users' invasion. Whereas the busway lane is made specifically for TransJakarta buses, so no vehicles may pass, except for certain vehicles and with police discretion. Therefore, the Provincial Government of DKI Jakarta and the Dirlantas Polda Metro Jaya must be consistent in law enforcement against traffic violators who are determined to break through the busway lane. Breakers of busway lanes must be dealt with firmly in accordance with applicable laws so that they can provide a deterrent effect. However, at the same time, preventive law enforcement is carried out in the form of massive and continuous socialization to road users.

The four policy strategies for developing BRT-based urban mass public transportation as stated above are believed by the authors to be able to overcome the problem of urban transportation in Jakarta. The four policy strategies are sustainable and equitable BRT-based mass public transport policy models, and the model is described as follows: 


\section{Figure 1 The Integrated BRT-Based Mass Transportation Policy Implementation Model}

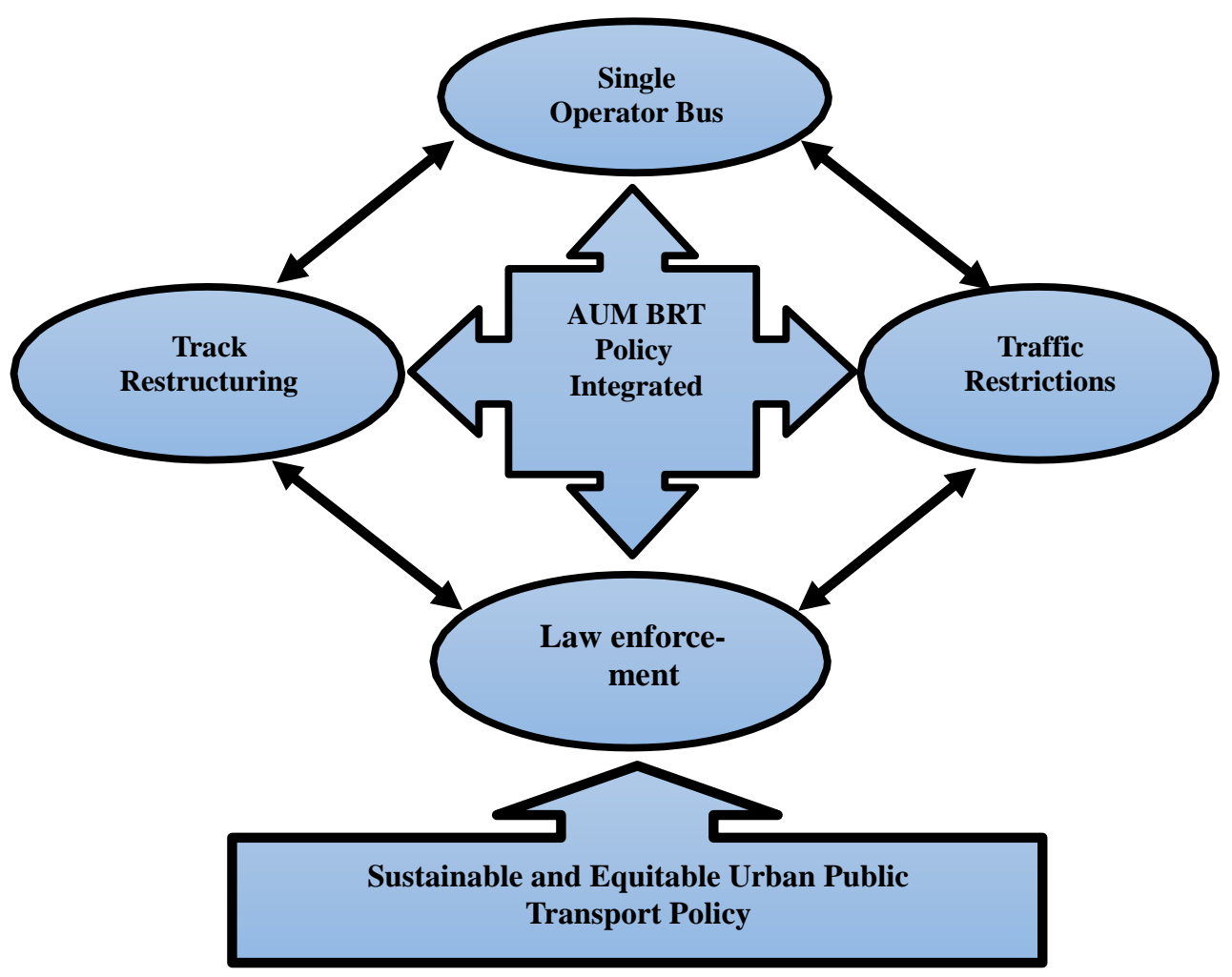

\section{CONCLUSION}

Policy choices for developing mass public transportation based on BRT seem to remain a rational choice for overcoming traffic congestion in Jakarta. The ideal model of policy implementation to be developed in the future is an integrated BRT-based mass transit public transport policy model, not only paying attention to its sustainability but also being just. The Provincial Government of DKI Jakarta should implement the management of mass public transportation into one operational management. The next need is to restructure routes based on community needs. In addition, the policy of developing mass public transportation based on BRT will only be effective when followed by a traffic restriction strategy. In addition, the effectiveness of policy implementation is also largely determined by the consistency and continuity of enforcement of the rules on which policy operates. 


\section{REFERENCES}

1. Arista, P. W. (2018). Implementasi Peraturan Menteri Perhubungan Nomor 27 Tahun 2015 Tentang Standar Pelayanan Minimal Angkutan Massal Berbasis Jalan di Kota Tangerang (Doctoral dissertation, Universitas Airlangga).

2. Chadwick, B. A., Bahr, H. M., \& Albrecht, S. L. (1991). Metode Penelitian Ilmu Pengetahuan Sosial. Sulistia ML, Mujianto Y, Sofwan A, Suharjito, penerjemah. Semarang (ID): IKIP.

3. DKI Jakarta Governor Regulation No. 103/2007 concerning Macro Transportation Patterns.

4. Guntur, N. F. (2019). Implementasi Kebijakan Bus Rapid Transit (Brt) Mamminasata di Kota Makassar (Doctoral dissertation, Universitas Negeri Makassar).

5. Hafis, A., Imam, R., Hakim, A., \& Haryono, B. S. (2014). Aktor Pelaksana Pengelolaan Transportasi Publik Perkotaan (Studi Kasus Bus Trans Metro Di Kota Pekanbaru). Jurnal WACANA, 16(4), 171-178.

6. Islamy, I. M. (1984). Prinsip-Prinsip Perumusan Kebijakan Negara. Jakarta: Bumi Aksara.

7. Miles, M. H., \& Huberman, A. A. (1984). Qualitative Data Analysis. Beverly Hills.

8. Moleong, L. J. (2002). Metodologi Penelitian Kualitatif. Bandung: Remaja Rosdakarya.

9. Munawar, A. (2007). Pengembangan Transportasi Yang Berkelanjutan", Pidato Pengukuhan Jabatan Guru Besar, Fakultas Teknik Universitas Gadjah Mada di Yogyakarta tanggal 7 Februari 2007.

10. Pambagio, A. (2013). Protes Publik Transportasi Indonesia. Jakarta: Gramedia Pustaka Utama.

11. Parekesit, D. (2014). Kebijakan Pengembangan Kota Jakarta Berwawasan Transportasi Publik (TOD) dan Berbasis Kereta Api yang Terintegrasi. Makalah, Universitas Indonesia, 16 Januari 2014.

12. Priyanto, D. F. (2018). Analisis Respon Masyarakat Terhadap Kebijakan Aglomerasi Transportasi Massal Bus Rapid Transit (BRT) Di Kabupaten Semarang. EFFICIENT Indonesian Journal of Development Economics, 1(3), 252-259.

13. Regional Regulation of the Province of DKI Jakarta Number 5 of 2014 concerning Transportation.

14. Sani, Z. (2010). Transportasi (Suatu Pengantar). Jakarta: UI-Press.

15. Subarsono. (2010). Analisis Kebijakan Publik Konsep, Teori dan Aplikasi. Yogyakarta: Pustaka Pelajar.

16. Suseno, D. P. (2019). Kajian Angkutan Massal Berbasis Rel Untuk Transportasi Berkelanjutan di Kota Semarang. Jurnal Teknik Sipil, 11.

17. Van Meter, D. S., \& Van Horn, C. E. (1975). The Policy Implementation Process A Conceptual Framework. Administration E Society, 6(4), 445-488. 
18. Wahab, S. A. (2002). Analisis Kebijaksanaan: Dari Formulasi Ke Implementasi Kebijaksanaan Negara. Jakarta: Bumi Aksara.

19. Wildon, G. L. (1939). The London Passenger Transport Board-A Public Transportation Trust. The ANNALS of the American Academy of Political and Social Science, 201(1), 118-123.

20. Winarno, B. (2016). Kebijakan Publik, Teori, Proses, dan Studi Kasus. Yogyakarta: CAPS.

21. Wright, L., \& Fjellstrom, K. (2002). Sustainable Urban Transport Sourcebook for PolicyMakers in Developing Cities. Germany: GTZ.

22. Wish, N. B. (1982). Improving Policy Making in Public Transportation. Public Administration Review, 42(6), 530-545.

23. Yafiz, M. (2002). Analisis Kinerja Jasa Transportasi Angkutan Kota di Kota Pekanbaru. Program Pasca Sarjana, Institut Pertanian Bogor. 